\title{
School Climate and the Work Attitude of Senior High School Teachers of Panabo City Division
}

\author{
Kathrina T. Tana ${ }^{1}$, Dr. Ronald S. Decano ${ }^{2}$ \\ ${ }^{I}$ Graduate Student, Doctor of Philosophy in Educational Management, Davao del Norte State College, Philippines \\ ${ }^{2}$ Dean, Institute of Advanced Studies, Davao del Norte State College, Philippines
}

\begin{abstract}
The study was conducted to determine the relationship between School Climate and Work Attitude of Senior High School teachers in Panabo City Division. It sought to identify the level of perceptions of Teachers towards School Climate and work attitudes. It also investigated significant difference on respondents in terms of their perception towards School climate and work attitude when analyzed according to Gender, Strand, and Length of Service. A descriptive-correlational research design was used in this study. SHS teachers were detailed as respondents. Based on findings, it was reported that teachers rated the school climate and work attitude as High. In terms of Gender, Strand, and Length of Service, the results reveal that there is no significant variation in teachers' perceptions of school atmosphere and work attitude. In addition, there is a strong link between school atmosphere and job attitude. In terms of school atmosphere and work attitude, senior high school teachers get a high ranking. There is no discernible difference in how SHS instructors feel about school atmosphere and work attitude. It was shown that there is a substantial link between school environment and instructors' work attitudes. In the light of the findings and conclusions, it is recommended that DepEd officials spearhead orientation-trainings to teachers. School administrators will be guided on the plans to be integrated in the curriculum. They may create strategies containing guidelines so that both teachers and administrators will be guided on properly sailing within the new curriculum.
\end{abstract}

Keywords- school climate, work attitude, senior high school

\section{INTRODUCTION}

$\mathrm{T}$ he initial implementation of the new curriculum has raised some social concerns. In a paper written by Burila (2012) in Crisol et al., (2014), he cited some community concerns in the implementation of the K12 program, like the readiness of the Philippine Government to undergo transitions. In this sense, our schools, especially the teachers, are facing new challenges in terms of the school condition and their work attitude brought about by this new paradigm shift in the landscape of the education system. The school is considered the second home for both students and teachers. Thus, it should be made comfortable, pleasant and safe since it is the extension of home. It is also a community where people, the physical structures and the atmosphere make up a place that may affect each other, contributing to the learning environment and school climate. Since the implementation of this new educational paradigm, though long-prepared by government, still confronted issues like strategic planning and new situations, senior high school teachers are in great adjustments both in their academic and economic dealings.
In the current situation, the senior high school classes and classrooms are integrated into the premise of the junior high school. There is not yet a clear provision or institutional policies that are especially directed for the Senior high school teachers to perform their roles effectively.

In this manner, senior high teachers may feel different knowing that at their level, they ought to be treated accordingly in the context of their new learning environment, given they have students with different needs. From this point of view, there is now a serious problem dealing with how these senior high teachers adjust with the implementation of $\mathrm{K}$ to 12 in line with their attitudes towards the new curriculum and how they perceive the school climate. Educational factors that have been found to predict developing teachers' disinterest in school are teachers' work attitudes towards school (e.g., Bryant \& Zimmerman, 2002) and teachers' perceptions of school climate (e.g., Perkins \& Jones, 2004). The K-12 vision aspires to be socioeconomically relevant as well. An expanded curriculum is the only way to achieve such a vision (Deped Primer, 2011). However, in order for any change to succeed or fail, it is necessary to examine people's views regarding it.

As defined by Sarong (2009), attitude is an inward feeling expressed by outward behavior. People always project on the outside what they feel on the inside. Nevertheless, people's attitudes are shaped by the facilities and environment through which they are mediated (Ferreira, 1995). In the Philippines, many criticisms have been told on the quality of public school education. Most common includes the competence of teachers and the quality of learning environment that are significant to students' everyday learning. Furthermore, school climate efforts also can increase job satisfaction and teacher retention, which is a significant matter given the elevated percentage of turnover in the field.

\section{METHODOLOGY}

\section{Research Design}

The study utilized a descriptive-correlational research design to thoroughly explain school climate as well as its purported relationships toward Senior High School teachers' attitudes. A descriptive study is one that records, analyzes and interprets existing conditions. It is characterized by non- 
manipulation of variable in natural rather than artificial setting.

The descriptive method was employed to obtain reliable and valid information and to describe and correlate the school climate and the work attitudes of senior high school teachers in the Panabo City division (Creswell, 2014).

\section{Research Locale and Sampling}

The study was conducted at Panabo City Division, Panabo City. The following schools offer Senior High schools. Panabo National High School, this school is the most significant public school in Panabo City. It is located at Brgy. Gredu, Panabo City. It offers thirteen specializations: Science, Technology, Engineering, and Mathematics (STEM) and Technical-Vocational, and Livelihood (TVL). Panabo City Senior High School, located at Brgy.New Visayas, Panabo City. This school was instituted in the year 2016. It offers academic Strands that offer ABM, HUMSS, and GAS programs. The school has twenty-eight senior high school teachers. San Vicente National High School is located at Brgy. San Vicente, Panabo City. It offers six specializations: General and Academic Strand (GAS) and Technical-Vocational, and Livelihood (TVL). Southern Davao National High School is located at Brgy. Southern Davao, Panabo City. It offers Technical Vocational and Livelihood (TVL) with five specializations. Little Panay National High School is located at Brgy. Little Panay, Panabo City. It offers technical-Vocational, and Livelihood (TVL) with two specializations. Antonio O. Floirendo National High School is located at Brgy. A.O. Floirendo, Panabo City. It offers General and Academic Strand (GAS) and Technical-Vocational, and Livelihood (TVL) with ten specializations. Don Manuel Javellana National High School is located at Brgy. DAPCO, Panabo City. It offers Technical-Vocational and Livelihood (TVL) with three specializations. Manay National High School is located at Brgy. Manay, Panbo City. It offers Technical-Vocational and Livelihood (TVL) with three specializations. Lastly, Quezon National High School is located at Brgy. Quezon, Panabo City It offers Technical-Vocational, and Livelihood (TVL) with one specialization.

The respondents of the study were Senior High School teachers in the Division of Panabo City. These teachers are under the Science, Technology, Engineering, and Mathematics (STEM), Accounting Business and Management (ABM), Humanities and Social Sciences (HUMSS), General Academic Strand (GAS) and TechnicalVocational, and Livelihood (TVL) strands. Universal Sampling was used to determine this study's respondents since all Senior High School teachers of Panabo City Division were selected. The distribution of the teacherrespondents is shown as follow:

\section{Data Gathering Procedure}

The following steps were undertaken in the gathering of data for this study:
Asking Permission to conduct the study. The researcher wrote a letter addressed to the office of the Schools Division Superintendent through the office of the Secondary School principal to allow the researcher to conduct the study. A letter was also sent to the principal through the Senior High School Coordinator asking Permission to conduct the administration of questionnaires to Senior High Teachers.

Administration and Retrieval of Questionnaires. After the survey questionnaires were administered to the respondents of the study, the gathered data were tallied, analyzed, and subjected to statistical analysis by the designated statistician.

Gathering and Tabulation of Data. The collection of data started with the giving of survey questionnaires to the senior high school teachers using attitude and perception inventory. The questionnaire were given to the teachers to get baseline information regarding the school climate and their attitude towards it.

After the test administration, the results were gathered and were subjected to statistical analysis following statistical tools: mean, t-test, t-test of correlated data for the test of difference, and Pearson, $r$ for the test of the relationship.

\section{Data Analysis}

The following statistical tools were used to analyse, analyze, and interpret the obtained data.

Mean and Standard Deviation was used to present mean ratings of the attitude and perception towards school climate of senior high school teachers.

T-test for the uncorrelated sample mean was used to test whether there is a significant difference in the perception towards school climate and Work Attitude of Senior high school teachers when analyzed according to sex and specialization.

Pearson's $r$ was used to see if there was a link between school environment and senior high school teachers' work attitudes.

\section{RESULTS AND DISCUSSIONS}

The $\mathrm{p}$ values of the relationship between School climate and Work attitude in terms of Institutional Environment are reported as follows: Job $(\mathrm{p}=.000)$, Salary $(\mathrm{p}=.000)$, Relationship ( $\mathrm{p}=.000)$, and Personal Career $(\mathrm{p}=.000)$. Since the probability of significance shown in Table 11 for between teachers' perception of School Climate and work attitude in terms of Institutional Environment are all less than the 0.05 alpha level thus, all the null hypotheses are rejected. Therefore, there is a significant relationship between teachers' perception on school climate and work attitude in terms of Institutional Environment. This implies that the higher is the perception of the faculty on the school climate, the higher is the teachers' work attitude towards Institutional Environment. Moreover, as the teachers' 
perception of all the components of school climate increases, their work attitude towards Institutional Environment also increases.

School Connectedness and engagement is a sub-indicator under Institutional Environment. This connectedness entails identification with the school and norms for widespread participation in school life for students, faculty, and families. Ruus et al. (2007) suggested that school connectedness is a powerful predictor associated with health and academic outcomes. Skiba (2004) added that school connectedness is associated with violence prevention. In this sense, it is clearly established that the institutional environment has a strong impact on the work attitude of teachers. Catalano et al. (2004) added that school connectedness is a protective factor against risky sexual violence and drug use behaviors. In this case, if school connectedness is solid and firm, then the institutional environment becomes positive, motivating the educators to increase the level of their work attitude.

\section{CONCLUSION}

Based on the findings mentioned above of the study, the following conclusions are drawn:

The senior high school teachers have a high rating in their perception towards School climate in terms of Safety, Relationship, Teaching, and Learning and Institutional Environment.

The senior high school teachers also have a high rating on work attitude in terms of their satisfaction in Job, Salary, Relationships, and Personal and Career Growth. This concludes that the teachers are happy and satisfied with the new curriculum.

There is no significant difference in the perception of senior high school teachers towards school climate. It is concluded that despite the Gender, Strand, and length of service, the teachers have the same perception towards school climate.

It is also concluded that there is no significant difference in the work attitude of senior high school teachers. This means that despite the Gender, Strand, and length of service, the teachers have the same work attitude.

Furthermore, it is found that there is a substantial link between school environment and senior high school teachers' work attitudes. The conclusion is that the school atmosphere has a direct impact on work attitudes.

\section{ACKNOWLEDGEMENT}

I, Kathrina T. Tana, would like to express my heartfelt gratitude to the following individuals who made a considerable influence to the success of this project. Dr. Ronald Decano, research adviser and Dean of Davao del Norte State College's Graduate School, for his encouragement in completing this study. The panel examiners, for their constructive criticism and suggestions, greatly aided in improving this manuscript. To my virtual friend and classmate Ma'am Gel Marie Buladaco and her brother Prof. Mark Van M. Buladaco for assisting me in completing and submitting my paper for publication.

I'd want to express my gratitude to my family, especially my husband Danilo, my sons Kraig and Kier, daughter Danykah, my parents and siblings for their support and affection. They all have kept me going, and without them, this research would not have been possible;

For all the hurdles created in getting this far in our PHD adventure, I thank my Ka-Super friends and colleagues at Panabo City National High School. Congratulations to all of us.

Finally, thanks to our all-powerful GOD, who made it all possible.

\section{REFERENCES}

\section{A. Bibliography}

[1] Dee, T. S. 2005. "A Teacher Like Me: Does Race Ethnicity or Gender Matter?" Understanding Teacher Quality, 95(2): 158165.

[2] Eggen, P., Kauchak, D. (2002). Strategies for teachers: Teaching content and thinking skills (4th edition). Needham Heights: M.A. Allyn and Bacon.

[3] Halpin, A. W. (1967). Theory and research in administration. New York: Macmillan.

[4] Honig, Meredith. 2006. Complexity and Policy Implementation: Challenges and Opportunities for the Field. In New Directions in Education Policy Implementation: Confronting Complexity, edited by M. Honig. Albany, NY: State University of New York.

[5] Lee, T., Cornell, D., Gregory, A., \& Fan, X. (2011).High suspension schools and dropout rates for black and white students.Education and Treatment of Children, 34, 167-192

[6] LitwinG.,\& Stringer R. (1968). Motivation and organizational climate.Boston: Harvard Business School Research Press.

[7] Locke, E. (1975). Personnel attitudes and motivation. Annual Review of Psychology, 457 -480.

[8] McBrein, J., \& Brandt, R. (1997). The language of learning: A guide to educational terms. Alexandria, VA: Association for Supervision and Development.

[9] Neal A., Griffin M. A., \& Hart P. M. (2000). The impact of organizational climate on safety climate and individual behavior. Safety Science Volume 34, Issues 1-3, 99-109

[10] Perkins, D., \& Jones, K. (2004).Risk behaviors and resiliency among physically abused adolescents. Child Abuse and Neglect, 28, 547-563

[11] Pirola-Merlo A., Hartel, C., Mann L., \&Hirst C. (2002).How leaders influence the impact of affective events on team climate and performance in R\&D teams. The Leadership Quarterly Volume 13, Issue 5, 561-581

[12] Spencer L. M., Pelote V., \& Seymour P. (1998).A causal model and research paradigm for physicians as leaders of change. New Medicine, 2:57-64 Current Science Inc. ISSN 10892524.

[13] Weber, J. (1995). Influences upon organizational ethical subclimates: a multi-departmental analysis of a single firm. Organizational Science 6, 509-523.

\section{B. Webliography}

[14] Ann, D. (2012). "What is personal Growth and Development?". Retrieved on February 6, 2017 from http://www.mdjunction.com/forums/positive-thinking discussions/lounge/3479921-what-is-personal-growthdevelopment

[15] Bernstein, D. A., \& Nash, P. W. (2008). Essentials of psychology (4th ed.). Boston: Cengage Learning. Retrieved February 
10

2017

from

http://books.google.com/books?id=4Do-bFrt9tUC.

[16] Blum, R. W., McNeely, C. A., \& Rinehart, P. M. (2002).Improving the odds: The untapped power of schools to improve the health of teens (Research report). Retrieved January 24, 2017 from http://www.med.umn.edu/peds/ahm/prod/groups/med/@pub/@ med/documents/asset/med_21771.pdf

[17] Bryk, A. S., Sebring, P. B., Allensworth, E., Luppescu, S., \& Easton, J. Q. (2010). Organizing schools for improvement: Lessons from Chicago. Chicago, IL: University of Chicago Press

[18] Burila, JM (2014). K to 12 Education in the Philippines: For better or for worse? Retrieved from http://www.academia.edu/6937076/K12_Education_in_the_Phili ppines_For_the_better_o r_for_w orse_Critique_Paper

[19] Centers for Disease Control and Prevention. (2009). School connectedness: Strategies for increasing protective factors among youth. Retrieved from http://www.cdc.gov/HealthyYouth/AdolescentHealth/pdf/connec tedness.pdf

[20] Department of Education (2011).K t o 12 B a s i c E d u c a t i o n Prog r a m Pri m e r D e p Ed U pd a tes. Retrieved from http://www.deped.gov.ph/

[21] Department of Education. (2010). B r i e f e r o $\mathrm{n} \mathrm{th}$ e e $\mathrm{n} \mathrm{h}$ a $\mathrm{n}$ c e d k 12 b a s i c d u c a ti o n p rog r a m. Retrieved from http://www.gov.ph/2010/11/02/briefer-on theenhanced-k12basic-education-program/

[22] Holmlund, H. and Sund, K. 2005. "Is the Gender Gap in School Performance Affected by the Sex of the Teacher?" Swedish Institute for Social Research. Retrieved May 8, 2006 from www.ne.su/research/ seminars/pdf/070313_2.pdf.

[23] Kaiser, A. (2011). Beginning Teacher Attrition and Mobility: Results from the First through Third Waves of the 2007-08 Beginning Teacher Longitudinal Study (NCES 2011- 318). U.S. Department of Education. Washington, DC: National Center for Education Statistics. Retrieved September 25, 2013 from nces.ed.gov/ pubsearch.

[24] Kerr, D., Ireland, E., Lopes, J., Craig, R., \& Cleaver, E. (2004).Citizenship education longitudinal study: Second annual report: First longitudinal study. Retrieved from https://www.education.gov.uk/publications/eOrderingDownload/ RB531.pdf

[25] Kelner S. R., \& C, O'Connell K. (1996).Managerial style as a behavioral predictor of organizational climate.Boston: Hay McBer. LDR-Organizational Climate.(2002). Organizational climate overview.Retrieved from June 11, 2002, from www.ldrgroup.comlclimateoverview.html.

[26] Kendziora, K., Osher, D., Chinen, M. (2008). Student connection research: Final narrative report to the Spencer Foundation.

[27] Luna, L (2013). Glance on Republic Act No. 10533. Retrieve from http://www.teachersessay.com/glance-on-republic-act-no$10533 /$

[28] National Association of Secondary School Principals (2016). "School Climate and Safety. Retrieved January 23, 2017 from https://principals.org/advocacy/learn-the-issues/school climateand-safety?SSO=true

[29] National Association of School Psychologists (NASP). (2010). Positive School Climate Strong interpersonal relationships and ongoing support for students' self-regulation create a positive context for learning. Retrieved January 23, 2017 from file:///C:/Users/Rex/Downloads/School_ClimatePLDec10_ftsp.p df

[30] National School Climate Council. (2007). The School climate challenge: Narrowing the gap between school climate research and school climate policy, practice guidelines and teacher education www.schoolclimate.org/climate/documents/policy/ climate-challenge-web.pdf

[31] National School Climate Center. (2017). The 12 Dimensions of School Climate Measured. Retrieved January 23, 2017 from http://www.schoolclimate.org/programs/documents/dimensions_ chart_pagebars.pdf

[32] Pennsylvania State Educators Association (PSEA). (2016). "The Power of Great Education: PSEA's 20/20 Vision for the Future. Retrieved January 24, 2017 from https://www.psea.org/uploadedFiles/LegislationAndPolitics/Visi on/Vision_PostiveAndSa feSchoolClimate.pdf

[33] Stevenson, K. R. (2006). School size and its relationship to student outcomes and school climate: A review and analysis of eight South Carolina state-wide studies. Retrieved from http://www.ncef.org/pubs/size_outcomes.pdf

[34] Taylor, T.C. (2015). "Making the connection between pay and work attitude".Retrieved on February 5, 2017 from http://www.payscale.com/compensation-today/2015/02/making the-connection-between-pay-and-work-attitude

[35] Teaching Commission. 2005. Teaching at Risk: A Call to Action. The Teaching Commission. Available at: http://ftp.ets.org/pub/corp/ttcreport.pdf

[36] Tymms, P. 2005. "Teacher Gender has no Effect on Pupil Performance." Retrieved February 7, 2017 from http://www.teachers org.uk.

[37] Wilson D. (2004). The interface of school climate and school connectedness and relationships with aggression and victimization. Journal of School Health. 2004;74:293- 299. [PubMed]

[38] Zwilling, M. (2016). "Your Success At Work Depends On Peer Relationships".Retrieved on February 7, 2017 from http://www.forbes.com/sites/martinzwilling/2016/01/07/your success-at-work-depends-on-peer-relationships/\#6cfe3cd44fa9

\section{Other Materials}

[39] Al Harthy, S. S. H., Jamaluddin, S., \&Abedalaziz, N. A. (2013).Teachers' Attitudes and Performance:An Analysis of Effects Due to Teaching Experience. International Interdisciplinary Journal of Education, 2(9), 889-894.

[40] Ahmad, M., \& Hussain, I. (2012).A Study of the Factors Affecting the Professional Performance of Teachers at Higher Education Level in Khyber Pakhtunkhwa.Academic Research ..., 2(2), 336-341.

[41] Ahmad, A., Sahak, R. (2009).Teacher-student attachment and teachers' attitudes towards work.JurnalPendidikdanPendidikan, 24 , pp. 55-71.

[42] Ahmad, A., Sahak, R. (2009). Teacher-student attachment and teachers' attitudes towards work.JurnalPendidikdanPendidikan, 24 , pp. 55-71.

[43] Abdulwahab, S., \& Usman, A. (2014).Competencies Required by Technical Drawing Teachers in Technical Colleges, 4(2), 32 37

[44] Attar-Schwartz, S. (2009). Peer sexual harassment victimization at school: The roles of student characteristics, cultural affiliation, and school factors. American Journal of Orthopsychiatry, 79, 407-420.

[45] Ballou, Dale, and Michael Podgursky. 1993. Teachers' Attitudes Toward Merit Pay: Examining Conventional Wisdom. Industrial and Labor Relations Review 47(1): 50-61

[46] Bradshaw, C. P., Waasdorp, T. E., \& O'Brennan, L. M. (2010).Whole-school approaches to bullying prevention: Engaging teachers and education support professionals in the prevention process. Technical report prepared for the National Education Association, Washington, DC.

[47] Bradshaw CP, Mitchell MM, O'Brennan LM, Leaf PJ.Multilevel exploration of factors contributing to the overrepresentation of African American students in office disciplinary referrals. Journal of EducationalPsychology. 2010;102:508-520.

[48] Brown KE, Medway FJ.(2007). School climate and teacher beliefs in a school effectively serving poor South Carolina African-American students: A case study. Teaching and Teacher Education. 2007;23:529-540.

[49] Catalano, R. F., Haggerty, K. P., Oesterie, S., Fleming, C. B., \& Hawkins, J. D. (2004). The importance of bonding to schools for healthy development: Findings from the social development 
research group. The Journal of School Health, 74, 252-262. doi:10.1111/j.1746-1561.2004.tb08281.x

[50] Corville-Smith, J., Ryan, B. A., Adams, G. R., \&Dalicandro, T. (1998).Distinguishing absentee students from regular attenders: The combined in- fluence of personal, family, and school factors. Journal of Youth and Adolescence, 27, $629-640$. doi:10.1023/A:1022887124634

[51] Crisol G. D., and Alamillo, J. B. (2014).A Comparative Study of the Attitudes between the Students and Teachers of Two Public Elementary Schools in Northern Mindanao toward the K to 12 Curriculum Shift. Mindanao State University- Iligan Institute of Technology, Mindanao State University- Naawan Campus.

[52] Department of Education. (2010). Discussion Paper o n t h e E n $\mathrm{h}$ a n c e d K +12 B a s ic Ed u c a t i o n Program.

[53] Elam, Stanley M. 1989.The Second Gallup/Phi Delta Kappa Poll of Teachers' Attitudes Toward the Public Schools. Phi Delta Kappan 70(10): 785-98.

[54] Eliot, M., Cornell, D., Gregory, A., \& Fan, X. (2010).Supportive school climate and student willingness to seek help for bullying and threats of violence. Journal of School Psychology, 48, 533553. doi:10.1016/j.jsp.2010.07.001

[55] Finnan, C., Schnepel, K., \& Anderson, L. (2003).Powerful learning environments: The critical link between school and classroom cultures. Journal of Education for Students Placed at Risk, 8, 391-418. doi:10.1207/S15327671ESPR0804_2

[56] Fonagy, P., Twemlow, S. W., Vernberg, E. M., Nelson, J. M., Dill, E. J., Little, T. D., \& Sargent, J. A. (2009).A cluster randomized controlled trial of child-focused psychiatric consultation and a school systems-focused intervention to reduce aggression. Journal of Child Psychology and Psychiatry, 50, 607-616. doi:10.1111/j.1469-7610.2008.02025.x

[57] Fonagy, P., Twemlow, S. W., Vernberg, E. M., Sacco, F. C., \& Little, T. D. (2005).Creating a peaceful school learning environment: The impact of an antibullying program on educational attainment in elementary schools.Medical Science Monitor, 11, CR317-325.

[58] Gede, N. T. (2001). Teachers Characteristics and Job Satisfaction of Secondary School Teachers in Bayelsa State. (Unpublished Masters Thesis), Rivers State University of Science and Technology.

[59] Gede, N. T. and Lawenson, O. A. (2011).Employee Characteristics and Job Performance of Staff of Bayelsa State Ministry of Education. Proceeding of the 2011 International Conference on Teaching Learning and Change (c) International Association for Teaching and Learning (1A).

[60] Gottfredson, G. D., Gottfredson, D. C., Payne, A. A., \&Gottfredson, N. C. (2005).School climate predictors of school disorder: Results from a national study of delinquency prevention in schools.Journal of Research in Crime and Delinquency, 42, 412- 444.doi:10.1177/0022427804271931

[61] Gottfredson, G. D., \&Gottfredson, D. C. (1989).School climate, academic performance, attendance, and dropout.(ERIC Document Reproduction Service No. ED 308225)

[62] Gottfredson, G. D., Gottfredson, D. C., Payne, A., \&Gottfredson, N. C. (2005).School climate predictors of school disorder: Results from national delinquency prevention in school. Journal of Research in Crime and Delinquency, 42, 421-444. doi:10.1177/0022427804271931.

[63] Gregory, A., Cornell, D., Fan, X., Sheras, P., Shih, T., \& Huang, F. (2010).Authoritative school discipline: High school practices associated with lower student bullying and victimization. Journal of Educational Psychology, 102, 483-496.

[64] Gregory, A., Cornell, D., Fan, X., Sheras, P., Shih, T., \& Huang, F. (2010).Authoritative school discipline: High school practices associated with lower student bullying and victimization. Journal of Educational Psychology, 102, 483-496. doi:10.1037/ a0018562

[65] Gregory, A., Cornell, D., \& Fan, X. (2011).The relationship of school structure and support to suspension rates for Black and White high school students. American Educational Research Journal, 48, 904-934. doi:10.3102/0002831211398531
[66] Gregory, A., \& Cornell, D. (2009). "Tolerating" adolescent needs: Moving beyond zero tolerance policies in high school. Theory Into Practice, 48, 106-113. doi:10.1080/00405840902776327

[67] Gruenert, S. (2008, March/April).School culture, they are not the same. Alexandria, VA: National Association of Elementary School Principals.

[68] Guo, P. (2012). School culture: A validation study and exploration of its relationship with teachers' work environment (Unpublished doctoral dissertation). Fordham University, New York.

[69] Hassan, B., Alias, M.B., and Awang, A. (2016). The Influence Of Teachers' Attitude On Their Occupational Task Performance In Teaching Engineering Drawing. Journal of Education and Social Sciences, Vol. 4, (June) ISSN 2289-9855

[70] Ispir, O.A. (2010). Teachers' Burnout Levels and Their Attitudes Towards Teaching Profession.EABR \& ETLC Conference Proceedings. Dublin, Ireland. pp. 229-233.

[71] Klein, J., \& Cornell, D. (2010).Is the link between large high schools and student victimization an illusion? Journal of Educational Psychology, 102, 933-946. doi:10.1037/a0019896

[72] Langdon, Carol, and Nick Vesper. 2000. The Sixth Phi Delta Kappa Poll of Teachers' Attitudes Toward the Public Schools. Phi Delta Kappan 81(8): 607-611.

[73] Lee, V., Smith, J., Perry, T., \&Smylie, M. A. (1999, October).Social support, academic press, and student achievement: A view from the middle grades in Chicago. Chicago: Consortium on Chicago School Research, Chicago Annenberg.

[74] Maraff, D. (2016). Improving School Climate and Student Behavior Through Positive Behavior Supports Through Positive Behavior Supports. North Central Regional Educational Laboratory (NCREL)

[75] Maslach J, Jackson SE. The measurement of experienced burnout. Journal of Occupational Behaviour. 1981;2:99-113

[76] McNeely, C. A., Nonnemaker, J. M., \& Blum, R. W. (2002).Promoting student connectedness to school: Evidence from the national longitudinal study of adolescent health. Journal of School Health, 72, 138-146. doi:10.1111/j.1746-1561.2002. tb06533.x

[77] Meerah, T.S.M., Halim, L., Rahman,S., Abdullah,R.T., Harun,H., Hassan,A.H, \&Ismai, A. (2010). Teaching marginalized children primary science teachers professional development through collaborative action research.Cypriot Journal of Educational Sciences, 5(1).

[78] Nesdale, D., \& Lawson, M. J. (2011).Social groups and children's intergroup attitudes: Can school norms moderate the effects of social group norms? Child Development, 82, 1594-1606. doi:10.1111/j.1467-8624.2011.01637.x

[79] Osterman, K. F. (2000). Students' need for belonging in the school community. Review of Educational Research, 70, 323367. doi: $10.3102 / 00346543070003323$

[80] Rani, G. and Tyage, M.K. (2013).Effect of Interpersonal Relationship on Attitude of Teacher Educators - An Empirical Study. International Journal of Education and Psychological Research (IJEPR) ISSN: 2279-0179 Volume 2, Issue 3, pp: 143147, August 2013

[81] Ransford, C.R., Greenberg, M.T., Domitrovich, C.E., Small, M., Jacobson, L. (2009).The Role of Teachers' Psychological Experiences and Perceptions of curriculum supports on the implementation of a social and emotional learning curriculum. School Psychology Review, 2009, 38(4), pp. 510-532.

[82] Reinke WM, Herman KC, Stormont M. (2013). Classroom-level positive behavior supports in schools implementing SW-PBIS: Identifying areas for enhancement. Journal of Positive Behavior Interventions. 2013;15:39-50.

[83] Rist, Marilee C. 1983. Out Nationwide Poll: Most Teachers Endorse the Merit Pay Concept. American School Board Journal 170(9): 23-27.

[84] Ruggai, J. R. and Agih, A.A. (2008).Experience and Qualification as Correlates of Teacher Job Performance in 
Secondary Schools in Bayelsa State. African Journal of Education Research and Development 2(1) September, 2008

[85] Ruus, V., Veisson, M., Leino, M., Ots, L., Pallas, L., Sarv, E., \&Veisson, A. (2007). Students' well-being, coping, academic success, and school climate. Social Behavior \& Personality, 35, 919-936. doi:10.2224/sbp.2007.35.7.919

[86] Skaalvik EM, Skaalvik S.(2007). Dimensions of teacher selfefficacy and relations with strain factors, perceived collective teacher efficacy, and teacher burnout. Journal of Educational Psychology. 2007;99:611-625

[87] Skiba, R., Simmons, A. B., Peterson, R., McKelvey, J., Forde, S., \&Gallini, S. (2004).Beyond guns, drugs and gangs: The structure of student perceptions of school safety. Journal of School Violence, 3, 149-171. doi:10.1300/J202v03n02_09

[88] Thapa, A., Cohen, J., Guffey, S., \& Higgins-D'Alessandro, A. (2013). A review of school climate research.Review of Educational Research, 83, 357-385.

[89] Thapa, A., Cohen, J., Higgins-D'Alessandro, A., \&Guffy, S. (2012, August). School climate research summary (Issue Brief No. 3). Bronx, NY: National School Climate Center.

[90] Thapa A, Cohen J, Guffey S, Higgins-D'Alessandro (2013). A review of school climate research. Review of Educational Research. 2013;83:357-385

[91] Wang, M. T., Selman, R. L., Dishion, T. J., \&Stormshak, E. A. (2010).A Tobit regression analysis of the covariation between middle school students' perceived school climate and behavioral problems.Journal of Research on Adolescence, 20, 274-286. doi:10.1111/j.1532-7795.2010.00648.x

[92] Welsh, W. N., Stokes, R., \& Greene, J. R. (2000).A macro-level model of school disorder.Journal of Research in Crime and Delinquency, 37, 243- 283.

[93] Wentzel, K. R. (1997). Student motivation in middle school: The role of perceived pedagogical caring. Journal of Educational Psychology, 89, 411-419. doi:10.1037/00220663.89.3.411

[94] White, B., and Beal, G. (1999). Violence in schools as perceived by preservice and in service teachers. Contemporary Education, $71(1), 31-8$

[95] Whitlock, J. L. (2006). Youth perceptions of life in school: Contextual correlates of school connectedness in adolescence.Applied Developmental Science, 10, 1329.doi:10.1207/s1532480xads1001_2

[96] Yates, S. M. (2007). Teachers' perceptions of their professional learning activities.International Education Journal, 8(2), 213221.

[97] Zohar, D. (2000). A group-level model of safety climate: testing the effect of group climate on microaccidents in manufacturing jobs. Journal of Applied Psychology 85, 587-596. 